\title{
PERGESERAN PERILAKU ANAK USIA SEKOLAH DALAM MENGGUNAKAN BAHASA LOKAL DI NEGERI TULEHU, KECAMATAN SALAHUTU, KABUPATEN MALUKU TENGAH
}

\author{
Pieter J. Pelupessy, Abdul R. Malawat \\ Program Studi Sosiologi Fakultas Ilmu Sosial dan Ilmu Politik \\ Universitas Pattimura \\ pelupessypieter@gmail.com
}

\begin{abstract}
Abstrak
Hasil penelitian menunjukkan bahwa penggunaan bahasa lokal di Negeri Tulehu, Kecamatan Salahutu Kabupaten Maluku Tengah mengalami pergeseran terhadap penggunaan bahasa Tulehu di kalangan generasi muda disebabkan karena perilaku generasi muda sendiri yang kurang memiliki perhatian dan kepedulian untuk belajar bahasa Tulehu. Selain itu juga kurangnya sosialisasi dan pewarisan dari orang tua pada anak-anak dalam menggunakan bahasa Tulehu sehari-hari. Bahasa Tulehu tidak diajarkan sebagai muatan lokal pada lingkungan pendidikan. Kondisi ini apabila tidak ada perhatian khusus dari masyarakat dan Pemerintah Negeri Tulehu, maka pada waktu-waktu mendatang penggunaan bahasa Tulehu sebagai identitas dapat menjadi hilang. Masyarakat dan Pemerintah Negeri Tulehu perlu menghidupkan kembali penggunaan bahasa Tulehu maupun kegiatan pembinaan bahasa Tulehu pada lingkungan keluarga sebagai basis pendidikan informal, maupun penggunaan bahasa Tulehu pada lingkungan pendidikan formal di Sekolah Dasar atau yang sederajat, karena pada lingkungan pendidikan tersebut generasi muda dapat beradaptasi dengan lingkungan setempat dalam penggunaan bahasa Tulehu. Serta membangun kesadaran bersama dikalangan warga masyarakat untuk peduli terhadap penggunaan bahasa sebagai identitas.
\end{abstract}

Kata Kunci: Bahasa, Anak, Pergeseran.

\begin{abstract}
The results showed that the use of local language in Negeri Tulehu, Salahutu District, Central Maluku Regency has shifted among the younger generation due to lack attention and awareness for learning Tulehu language itself. In addition, there is also a lack of socialization and inheritance from parents to their children in using the Tulehu language every day. Tulehu language is not taught as a local content in an educational environment. If there is no special concern from the community and the Government of Negeri Tulehu, then in the future the use of the Tulehu language as an identity may disappear. The community and the Government of Negeri Tulehu need to revive the use of Tulehu language as well as the activities of fostering this language in family environment as the basis for informal education, as well as for formal education in elementary schools or the equivalent, because in this educational environment the younger generation can adapt to use the Tulehu language, also build mutual awareness among community members to care about the use of language as identity.
\end{abstract}

Keywords: Language, Kids, Shift 


\section{Pendahuluan.}

Masyarakat Indonesia yang mendiami berbagai negeri adat, pada umumnya merupakan masyarakat dengan dwibahasa, karena mereka memiliki bahasa lokal yang berbeda-beda. Dalam berinteraksi, masyarakat sering menggunakan bahasa sebagai alat komunikasi yaitu lebih dari satu. Bahasa yang sering digunakan dalam interaksi antara lain bahasa Indonesia dan bahasa daerah (bahasa ibu). Bahasa daerah (bahasa ibu) sering digunakan untuk berkomunikasi dalam lingkungan keluaraga maupun dalam pergaulan hidup di lingkungan masyarakat yang bersangkutan. Penggunaan bahasa Indonesia untuk berkomunikasi dalam situasi resmi. Pada masyarakat adat tertentu, bahasa daerah (bahasa ibu) merupakan kebanggaan karena terkait dengan identitas

Pada hakikatnya, dalam kehidupan sehari-hari, seseorang tidak lepas dari keharusan berinteraksi dengan orang lain. Pada saat berinteraksi seseorang menyampaikan pendapat dan pandangan dalam satu bahasa yang saling dimengerti. Melalui bahasa satu gagasan atau ide seseorang tersampaikan dengan baik, sehingga dapat dipahami apabila dalam berinteraksi, maupun segala kegiatan manusia, bahasa memegang peran penting. Bahasa merupakan unsur kebudayaan, sehingga tanpa bahasa manusia sulit untuk melanjutkan hidup dengan orang lain.

Setiap pulau di Maluku mempunyai bahasa tersendiri dan dalam satu pulau, setiap desa mempunyai bahasa sendiri. Hal tersebut sejalan dengan penelitian SIL (2006) dalam Bahasa-Bahasa di Indonesia yang menyatakan bahwa terdapat 101 bahasa daerah di Maluku. Sementara itu, Badan Bahasa dalam "Bahasa dan Peta Bahasa di Indonesia" (2014) baru mengidentifikasi sekitar 51 bahasa daerah di wilayah ini (diduga jumlah tersebut masih akan bertambah karena hingga saat ini masih terus dilakukan pengumpulan data di daerah-daerah yang bahasanya belum teridentifikasi). Kenyataan itu menunjukkan betapa beragamnya bahasa daerah yang ada di wilayah Maluku jika dibandingkan dengan provinsi lain di Indonesia.

Sayangnya, keberagaman bahasa tersebut tidak terpelihara dengan baik. Dominasi pemakaian bahasa Melayu-Ambon dalam komunikasi sehari-hari menekan pemakaian bahasa-bahasa daerah hampir di seluruh wilayah Provinsi Maluku. Di beberapa daerah, orang tua tidak lagi menurunkan bahasa ibunya kepada anak-anak mereka. Akibatnya, seiring dengan waktu, bahasa Melayu-Ambon yang dahulu merupakan bahasa kedua bagi beberapa etnis di Maluku menggeser kedudukan bahasa lokal dan berkembang menjadi bahasa ibu bagi etnis-etnis tersebut. Fenomena demikian semakin melemahkan kedudukan 
bahasa-bahasa daerah yang merupakan salah satu kekayaan budaya masyarakat Maluku, termasuk juga masyarakat adat di Negeri Tulehu.

Penggunaan bahasa daerah adalah suatu bahasa yang dituturkan oleh suatu masyarakat yang mendiami suatu wilayah tertentu. Keberadaan bahasa daerah atau bahasa lokal sangat erat dengan eksistensi suku bangsa tersebut. Bahasa menjadi unsur pendukung utama tradisi dan adat istiadat. Bahasa juga menjadi unsur pembentuk sastra, seni, kebudayaan, hingga peradaban suatu suku bangsa. Bahasa daerah dipergunakan dalam berbagai upacara adat, maupun dalam percakapan serta pergaulan hidup sehari-hari. Bahasa daerah merupakan unsur pembentuk budaya daerah dan sekaligus budaya nasional. Bahasa daerah yang digunakan oleh masyarakat adat di Negeri Tulehu masih dipergunakan oleh generasi tua sebagai alat komunikasi, sekaligus juga sebagai jati diri masyarakat.

Dewasa ini dijumpai bahwa, dalam pergaulan hidup sehari-hari di Negeri Tulehu masih ada orang tua-tua yang pasih berbicara dengan menggunakan bahasa lokal, tetapi dikalangan generasi muda penggunaan bahasa lokal makin berkurang. Hal ini menunjukkan adanya pergeseran nilai ketika mereka berinteraksi dengan menggunakan bahasa daerah. Dalam era modern ini, bahasa daerah sudah jarang dipergunakan, karena proses pewarisan, pelestarian, dan sosialisasi bahasa dari generasi yang satu ke generasi berikutnya menjadi terputus, dan dikhawatirkan bahwa suatu waktu bahasa Tulehu dapat menjadi punah.

Tidak sedikit bahasa daerah di Maluku yang terancam punah, seperti bahasa Amahai, bahasa Hoti, bahasa Piru, Hukumina, bahasa Kamarian, dan bahasa Kayeli. Dua diantaranya bahkan telah punah, seperti bahasa Moksela dan bahasa Palamata. Tidak tertutup kemungkinan, beberapa tahun yang akan datang bahasa-bahasa daerah yang saat ini masih produktif akan segera mengalami proses kepunahan. Bila hal itu terjadi, dikhawatirkan masyarakat Maluku akan kehilangan identitas atau jati dirinya yang pada akhirnya berdampak pada munculnya berbagai permasalahan dalam masyarakat.

Negeri Tulehu terletak dipulau Ambon, Kecamatan Salahutu, Kabupaten Maluku Tengah, Provinsi Maluku. Negeri Tulehu merupakan Negeri terbesar di kecamatan Salahutu, merupakan komunitas Salam atau Islam tua yang ada di Maluku, yang mana dahulunya Tulehu adalah negeri yang memiliki kaitan dengan Kerajaan besar Hitu. Menurut sejarah Negeri Tulehu yang dalam bahasa tanah Aman Turehui. Pada awalnya 
negeri ini terletak pada daerah perbukitan atau pegunungan. Menurut tua-tua adat Negeri Tulehu, penduduk Negeri Tulehu itu terbagi atas dua yaitu penduduk lama dan penduduk baru. Penduduk asli memiliki nenek moyang yang berasal dari Pulau Seram yaitu sekitar Teluk Elpaputi di Seram Barat, maupun Seram Bagian Timur, dan di sekitar daerah Salahutu juga terdapat penduduk yang berasal dari Arab dan Jawa. Mereka ini datang secara berkelompok melalui jalur laut dengan kora-kora, atau belang.

Bahasa di Negeri Tulehu, Kecamatan Salahutu, Kabupaten Maluku Tengah biasa disebut dengan nama bahasa Uli Solemata. Penggunaan bahasa lokal ini sebenarnya tergantung pada setiap masyarakat pendukung bahasa tersebut. Realitas saat ini dijumpai yaitu, dalam hidup keseharian, generasi tua lebih cenderung memakai bahasa lokal dan generasi muda memakai bahasa Melayu-Ambon dan bahasa Indonesia. Penggunaan bahasa lokal untuk berinteraksi di dalam keluarga sudah makin berkurang dan dikhawatirkan dapat hilang apabila tidak ada kepedulian dari masyarakat untuk melestarikannya. Untuk itu, pembiasaan berbahasa lokal perlu dihidupkan kembali pada anak-anak, baik di rumah maupun sekolah, dan tempat lainnya. Usaha menanamkan kembali kesadaran menanamkan penggunaan bahasa Tulehu, memiliki niali penting bagi penutur bahasa Tulehu, karena bahasa Tulehu memiliki keterkaitan yang erat dengan identitas sebagai anak Negeri.

\section{Metode Penelitian.}

Penelitian ini menggunakan pendekatan kualitatif karena bertujuan untuk mengetahui, memahami, dan menjelaskan bagaimana masyarakat khususnya anak usia sekolah dalam penggunaan bahasa lokal, serta melihat faktor apa saja yang menyebabkan pergeseran perilaku anak dalam penggunaan bahasa lokal. Penelitian ini dilaksanakan di Negeri Tulehu, Kecamatan Salahutu, Kabupaten Maluku Tengah, Maluku. Pengambilan data primer dilakukan melalui wawancara terhadap sejumlah informan yang dianggap terlibat secara langsung dalam penggunaan bahasa lokal di Negeri Tulehu, khususnya anak-anak usia sekolah. 


\section{Temuan dan Pembahasan.}

Pengetahuan masyarakat tentang penggunaan bahasa lokal di Negeri Tulehu sebagai sarana komunikasi yang efektif untuk menyampaikan pesan pada orang lain. Bahasa lokal atau bahasa daerah merupakan unsur pembentuk budaya daerah sekaligus budaya nasional. Bahasa daerah merupakan jati diri masyarakat. Menghadapi era di Negeri Tulehu masih ada, dan masih digunakan oleh orang tua-tua.

Pengetahuan anak usia sekolah dalam penggunaan bahasa lokal di Negeri Tulehu oleh anak sekolah atau kalangan generasi muda yaitu mereka tidak bisa berkomunikasi dengan menggunakan bahasa lokal secara lancar karena mereka terbiasa menggunakan bahasa Melayu-Ambon, dan di sekolah menggunakan bahasa Indonesia. Dewasa ini orang tua ketika berbicara menggunakan bahasa Tulehu, mereka tidak mengerti. Menurut mereka, hal ini disebabkan karena orang tua tidak pernah mengajarkan bahasa Tulehu. Dampak pergeseran penggunaan bahasa Tulehu karena orang tua ketika berkomunikasi dengan sesama usia menggunakan bahasa Tulehu, sedangkan dengan anak-anak menggunakan bahasa Melayu-Ambon. Pengetahuan masyarakat pendatang tentang penggunaan bahasa lokal di Negeri Tulehu yaitu mereka tidak dapat berbicara menggunakan bahasa Tulehu dengan lancar karena mereka juga memiliki bahasa lokalnya sendiri seperti orang Buton, Jawa, dan lainnya. Dalam pergaulan hidup sehari-hari, ada pendatang yang sama sekali tidak bisa menggunakan bahasa Tulehu, tetapi ada yang bisa menggunakan bahasa Tulehu karena mereka ada yang kawin dengan masyarakat asli Negeri Tulehu.

Pengetahuan masyarakat tentang pergeseran bahasa Tulehu ini disebabkan karena faktor perpindahan maupun mobilitas penduduk, dan pengaruh budaya yang berasal dari luar. Hal ini dapat terjadi karena Negeri Tulehu merupakan daerah transit bagi semua orang masuk ke daerah ini. Pergeseran dalam menggunakan bahasa Tulehu juga disebabkan karena pewarisan dari orang tua yang sangat kurang, penggunaan bahasa yang sudah terkontaminasi dengan bahasa pergaulan (bahasa gaul). Proses bergesernya bahasa Tulehu dalam hidup keseharian masyarakat Negeri Tulehu karena pengaruh budaya baru, hadirnya internet, televisi. Secara teoritis, pergeseran ini disebabkan karena proses perubahan sosial yang terus berlangsung dengan beberapa dimensi yaitu: a). Dimensi struktural dalam lembaga Mengacu pada perubahan-perubahan dalam bentuk struktur masyarakat, menyangkut peranan, munculnya peranan baru, perubahan dalam kelas sosial, dan perubahan sosial; b). Dimensi kultural, mengacu pada perubahan kebudayaan 
dalam masyarakat. Perubahan ini meliputi; c). Inovasi kebudayaan merupakan komponen internal yang memunculkan perubahan sosial dalam suatu masyarakat. Inovasi kebudayaan yang paling mudah ditemukan adanya teknologi baru. Kebutuhan masyarakat yang semakin kompleks memaksa individu untuk berfikir kreatif dalam upaya untuk memenuhi kebutuhan hidup; d). Difusi merupakan komponen eksternal yang mampu menggerakan terjadinya perubahan sosial. Sebuah kebudayaan mendapat pengaruh dari budaya lain, yang kemudian memicu terjadinya perubahan kebudayaan dalam masyarakat yang hendak menerima unsur-unsur kebudayaan tersebut.

Pergeseran dalam penggunaan bahasa Tulehu karena perilaku anak usia sekolah ketika berinteraksi dengan teman sesamanya. Apabila mereka terus menggunakan bahasa Tulehu, di mata teman-teman yang berbeda asal-usul, dianggap kolot., dan mereka merasa minder. Dapat dikemukakan bahwa, dampak negatif dari pergeseran bahasa Tulehu yaitu generasi penerus akan hilang kepercayaannya. Dapat dikemukakan bahwa, bahasa sebagai sarana komunikasi yang sangat efektif untuk mengatakan sesuatu kepada orang lain perlu dilestarikan. Bahasa lokal (bahasa Tulehu) merupakan jati diri masyarakat sehingga kalangan generasi muda perlu menyadarinya secara baik.

Bahasa Tulehu yang masih ada dan digunakan oleh generasi orang tua, perlu mewariskannya kepada generasi muda, terutama pada anak usia sekolah. Pewarisan bahasa Tulehu dari orang tua sehingga perlu adanya usaha membangun kesadaran baru secara bersama. Adapun faktor yang mempengaruhi pergeseran bahasa Tulehu yakni perilaku generasi muda sendiri yang kurang memiliki perhatian dan juga kepeduliaan untuk belajar bahasa Tulehu perlu digalang kembali oleh masyarakat, dan peran tokoh masyarakat merupakan kunci keberhasilan. Masyarakat dan Pemerintah Negeri Tulehu perlu menghidupkan kembali bahasa Tulehu melalui pembinaan pada lingkungan keluarga sebagai basis pendidikan informal, dan lingkungan pendidikan formal di Sekolah Dasar merupakan arena penting untuk membiasakan anggota masyarakat dalam menggunakan bahasa Tulehu.

Untuk itu dapat dikemukakan kesimpulan bahwa, pergeseran perilaku anak usia sekolah dalam menggunakan bahasa lokal di Negeri Tulehu karena lemahnya pewarisan dari orang tua yang sangat kurang, menyebabkan kesadaran generasi muda untuk belajar dan untuk menguasai bahasa tulehu menjadi kurang, serta sosialisasi bahasa Tulehu dalam 
keluarga dan masyarakat yang makin kurang. Bahasa Tulehu tidak diajarkan sebagai muatan lokal pada lingkungan pendidikan.

\section{Kesimpulan.}

Bahasa lokal atau bahasa daerah negeri Tulehu sebagai identitas masyarakat setempat. Realitas kekinian menunjukkan bahwa generasi muda negeri setempat tidak memahami secara baik bahasa lokal negeri Tulehu. Hal ini disebabkan selain proses sosialisasi dari orang tua kepada generasi berikutnya tidak berlangsung, namun tingkat kesadaran dan motivasi generasi muda untuk mempelajari bahasa dimaksud masih rendah.

\section{Daftar Pustaka.}

Chaer, Abdul dan Leonie Agustina. 2004. Sosiolinguistik Perkenalan Awal. Jakarta: Rineka Cipta.

Depdikbud. 1999, Penelitian Tindakan Kelas. Jakarta : Depdikbud.

Kramsch, Claire. 1998. Language and Culture. Oxford: Oxford University Press

Lauder, Multamia RMT. 2006. "Revitalisasi Bahasa Minoritas". Makalah dalam Seminar Internasional Penyelamatan BahasaBahasa yang Terancam Punah, Jakar

Sembiring, A. W. (2015). Pergeseran dan Pemertahanan Bahasa di dalam Perkawinan Campuran: Sebuah Studi Kasus dalam Keluarga Suku Karo. Tesis. Medan:

Setiawan, A., 2006, Pengantar Statistika, Graha Ilmu, Yogyakarta.

SIL International. 2006. Bahasa-Bahasa di Indonesia. Edisi Kedua. Jakarta: SIL International, Cabang Indonesia.

Smarapradhipa.2005.(http://winawimala.wordpress.com/author/winawimala/). diakses tanggal 10 Januari 2012.

Unimed. Smith-Christmas, C. (2014). Being Socialised into Language Shift: the Impact of Extended

Yagmur, K., Bot, K. De, \& Korzilius, H. (1999). Language Attrition, Language Shift and Ethnolinguistic Vitality of Turkish in Australia. Dalam Journal of Multilingual and Multicultural Development. Vol. 20, p. 51--69.

Thohir, Mudjahirin. 2007. Memahami Kebudayaan: Teori, Metodologi, dan Aplikasi. Semarang: Fasindo. 
Vol. 4 No. 2 Oktober 2021, Hal. 34-41

Tarigan, H. Guntur. 1984, Prinsip-prinsip Dasar Sastra. Bandung: Angkasa. 